\title{
Annular a' Velocity
}

National Cancer Institute

\section{Source}

National Cancer Institute. Annular a' Velocity. NCI Thesaurus. Code C127535.

The maximum rate of the annular motion during late diastole (active ventricular filling). 